\title{
The Relationship between Online Vendor Attributes and Online Customer Relationship Quality
}

\author{
Xiang-Yu MENG ${ }^{1, a}$, Hua $\mathrm{LI}^{1, \mathrm{~b}^{\star}}$ and Xiao-Yang YANG ${ }^{2, \mathrm{c}}$ \\ ${ }^{1}$ Zhuhai College of Jilin University, Zhuhai, China \\ ${ }^{2}$ Macau University of Science and Technology, Macau, China \\ ajilinuniv@163.com, 'lihuajluzh@163.com, 'sscolins@163.com \\ *Corresponding author
}

Keywords: Online Vendors' Attributes, Merchandise, Price Perception, Relationship Quality

\begin{abstract}
This paper aims to examine the relationship between merchandise, website navigation, price perception and online relationship quality. The findings indicate that merchandise has a significant effect on relationship quality. Relationship value had an indirect effect on relationship strength and citizenship behavior through relationship quality.
\end{abstract}

\section{Introduction}

Many researchers and managers maintain that one of the key goals of marketing is to build and sustain strong customer relationships (Bagozzi, 1995; DeWulf, Odekerken-Schröder, \& Iacobucci, 2001; McKenna, 1991). Relationship marketing is a contemporary marketing practice that enables a selling firm to gain greater insight into each individual customer's motivation for purchasing products (Gronroos, 1990). In order to successfully service online consumers, online vendors should know exactly what the consumers expect from them and how to build the customer relationships and improve the online relationship quality.

The purpose of this study is to propose and test the relationship between online vendors attributes include merchandise, website navigation, price perception and online relationship quality.

\section{Merchandise}

Findings from empirical studies have provided evidence that merchandise was the most important attribute to enhancing both trust and satisfaction (Byoungho \&Parkal., 2006). Perceptions of merchandise quality play a central role in a consumer's evaluative process (Dodds et al., 1991; Kerin et al., 1992; Zeithaml, 1988). Research has demonstrated that the effect of perceived quality on customer loyalty is direct (Cronin, Brady \& Hult, 2000) as well as indirect through value (Cronin et al., 2000; Sirohi,McLaughlin \& Wittink, 1998). Conceptually, merchandise quality is viewed very broadly as an attitude-like judgment of superiority or excellence (Zeithaml, 1988).

In a study to identify perceived quality constructs of consumers' durable goods, perceived merchandise quality played a crucial role affecting the purchase choices. Cronin, Brady and Hult (2000) also indicated the importance of merchandise quality on consumer decision making. But the importance of the merchandise quality influences on satisfaction and store loyalty are largely ignored (Parasuraman et al.,1994). As a consequence, this study considers merchandise quality as an antecedent and investigates its effect on online relationship quality.

\section{Website Navigation}

Good quality e-businesses provide current and future customers with pleasant online experiences. Researchers have studied the impact that web site navigation and graphics have on customer perceptions of the online shopping experience (Ariely, 2000; Hoffman \& Novak, 1996; Hoque \& Lohse, 1999; Lynch \& Ariely, 2000; Schlosser \& Kanfer, 1999). One can measure the success of an e-business by the number of online customer of visits, purchases, repeat business, and the 
company's profits.

The parameter of navigation has been widely applied in many studies in the context of measuring online service quality in recent years (Ranganathan \& Ganapathy, 2002) and it is one of the composed parameters in WebQUAL and SITEQUAL scales. It is considered as an important measurement parameter because it shapes the first impression if customer has little or no idea about the online vendor and consumers are more likely to buy the products or even revisit the site if it is attractive to them.

\section{Price Perception}

In the existing literature, price perception is what a consumer gives up or sacrifices in order to obtain a product (Zeithaml 1988). Lichtenstein et al. (1993) suggest that perceptions of price positively correlate with price seeking. The negative role of price perception comprises four dimensions namely price consciousness, value consciousness, sale proneness and coupon proneness. The extant research on price perceptions can be categorized into two themes: (1) exploration and identification of antecedents to price perceptions (Bolton \& Alba, 2006; Campbell, 2007) and (2) examination of the impact of price perceptions on consumers' attitudinal and behavioral outcomes (Daskalopoulou \& Petrou, 2006). Findings from both streams provide insights into the study of price perceptions under various pricing contexts (e.g., Homburg, Hoyer, \& Koschate, 2005) with respect to consumers reactions’ to a seller’s pricing strategy (Herrmann et al., 2007).

\section{Online Relationship Quality}

Previous research on relationship marketing uses two or three distinct dimensions to conceptualize the construct of relationship quality. Relationship quality can be analyzed from four aspects (satisfaction, commitment, confidence benefits/trust, and social benefits) which have significant direct impact on customer loyalty. For example, Crosby et al. (1990) and Dwyer et al. (1987) use two dimensions, relationship satisfaction and trust, to be indicators of the higher-order construct of relationship quality. Leuthesser (1997) further considers relationship commitment as the third dimension of relationship quality. While most studies revealed the mediating effects of the relational constructs of trust, satisfaction, and commitment, several studies have suggested using a global relationship construct, relationship quality (De Wulf, et al., 2003).

Based on the literature, Key indicators of relationship quality, which is viewed as the most critical outcome of relationship building, are relationship satisfaction, trust and relationship commitment.

\section{Research Model and Hypotheses}

Hypothesis 1: Merchandise has a positive and direct influence on online relationship quality.

Hypothesis 2: Website navigation has a positive and direct influence on online relationship quality.

Hypothesis 3: Price perception has a positive and direct influence on online relationship quality.

\section{Method}

The present study adopts a quantitative methodology, guided by the positivist / scientific realism paradigm. In this research, the target population for this research consists of online vendors' clients, who have online purchasing experience. They have more potential to need online purchasing in the future, and are willing to develop long-term relationship with their existing online vendors.

The survey was concerned with the relationship development between the online vendors and their client in an electronic business-to-consumer context.

Paper questionnaires were distributed to the student sample in with instruction. Most surveys were collected in online questionnaires. Many researchers have employed online register lists or databases to get the sample for their online consumer surveys. All the data collected from the web questionnaires were automatically recorded in the background database for further data transformation. The combination of data generated from web questionnaires and handout 
questionnaires produced no extreme errors in the estimates, and provided reliable results for most of the variables.

\section{Model and Hypotheses Testing}

Table 1 Structural Model Testing Results

\begin{tabular}{|c|c|c|c|c|}
\hline Path & $\begin{array}{c}\text { Hypothesi } \\
\mathrm{s}\end{array}$ & Estimates & T-value & $\begin{array}{c}\text { Supporte } \\
\mathrm{d}\end{array}$ \\
\hline $\begin{array}{c}\text { Merchandise } \rightarrow \\
\text { Online Relationship } \\
\text { Quality }\end{array}$ & $\mathrm{H} 1$ & 0.409 & $5.754 * * *$ & $\mathrm{Y}$ \\
\hline $\begin{array}{c}\text { Website } \\
\text { Navigation } \rightarrow \text { Online } \\
\text { Relationship Quality }\end{array}$ & $\mathrm{H} 2$ & -0.261 & -1.804 & $\mathrm{~N}$ \\
\hline $\begin{array}{c}\text { Price Perception } \rightarrow \\
\text { Online Relationship } \\
\text { Quality }\end{array}$ & $\mathrm{H} 3$ & -0.081 & -1.306 & $\mathrm{~N}$ \\
\hline $\begin{array}{l}* p<.05 * * p<.01 * * * p<.001 \\
* \text { Y supported } ; * * \mathrm{~N}=\text { not supported }\end{array}$ \\
\hline
\end{tabular}

The main part of data analysis focused on hypothesis testing. A structural equation modeling (SEM) procedure was employed to test these hypotheses. Essentially, SEM may be viewed as a combination of exploratory factor analysis and multiple regression analyses. In contrast to exploratory factor analysis, SEM demands that the (presumably causal) structure of inter variable relations, grounded in theory and/or empirical findings, be specified a priori.

The analyses were conducted using AMOS 21, and followed guidelines suggested by Ullman (2001). AMOS was chosen over other model fitting programs such as LISREL and EQS, for its unique strength in preventing errors in model specification, and its extensive bootstrapping capabilities, which is an effective tool for dealing with non-normal data.

Based on the t-values of the standardized parameter estimates in above tables, a summary of the structural model testing results is shown in Table 1.

According to Table 1, the results fully supported Hypothesis 1. While Hypothesis 2 and 3 are not supported.

\section{Conclusions}

The objective of this dissertation was to develop a model of the determinants and outcomes of online relationship quality in electronic business to customer context.

A key empirical finding in our study is the relative importance of merchandise in building online relationship quality. Therefore, online vendors are required to maintain competitive merchandise. Merchandise is usually the core part that consumers purchase. Thus, merchandise may be an important determinant of online customer relationship quality.

The insignificant association between website navigation and online relationship quality may be due to the widespread use of web design technology, many sites navigation have been improved substantially. The lack of differentiation found among websites. For example, most online vendors use the same website navigation approach towards every customer, regardless of the customer's experiences.

The insignificant association between price perception and online relationship quality may be explained by the fact that price perception may have impact on customer satisfaction in short term, however it has little effect on customer trust or commitment in long term. As a consequence, it is easy to accept that price perception has no effect on the online relationship quality.

Further studies should examine online relationship quality in other countries. We believe that the results may be different in different culture. Besides, there is a need for an investigation of online 
relationship quality among subcultures, for example, the older generation.

\section{References}

[1] Bagozzi, \& Richard P. (1995). Reflections on Relationship Marketing in Consumer Markets. Journal of the Academy of Marketing Science, 23 (9), 272-77.

[2] Wulf, K. D., Odekerken-Schröder, G., \& Iacobucci, D. (2001).Investments in Consumer Relationships: A Cross- Country and Cross-Industry Exploration. Journal of Marketing, 65 (10), 33-50.

[3] McKenna, R. (1991). Marketing Is Everything. Harvard Business Review, 69 (1-2), 65-79.

[4] Gronroos, C. (1990). Relationship approach to marketing in service contexts: the marketing and organizational behavior interface. Journal of business research, 20(1), 3-11.

[5] Byoungho Jin.,\& Jin Yong Park (2006).The Moderating Effect of Online Purchase Experience on the Evaluation of Online Store Attributes and the Subsequent Impact on Market Response Outcomes. Advances in Consumer Research, 33(11), 203-211.

[6] Dodds, W. B. (1991). In search of value: how price and store name information influence buyers' product perceptions. Journal of Services Marketing, 5(3), 27-36.

[7] Kerin, R. A., Varadarajan, R. R., \& Peterson, R. A. (1992). First-mover advantage: A synthesis, conceptual framework, and research propositions. Journal of Marketing, 56(4), 33-52.

[8] Parasuraman, A., Zeithaml, V. A., \& Berry, L. L. (1988). Servqual. Journal of retailing, 64(1), 12-37.

[9] Cronin Jr, J. J., Brady, M. K., \& Hult, G. T. M.(2000). Assessing the effects of quality, value, and customer satisfaction on consumer behavioral intentions in service environments. Journal of retailing, 76(2), 193-218.

[10] Sirohi, N., McLaughlin, E. W., \& Wittink, D. R. (1998). A model of consumer perceptions and store loyalty intentions for a supermarket retailer. Journal of retailing, 74(2), 223-245.

[11] Zeithaml, V. A. (1988).Consumer Perceptions of Price, Quality and Value: A Means-End Model and Synthesis of Evidence. Journal of Marketing, 52 (7), 2-22.

[12] Parasuraman, A., Zeithaml, V.A., \& Berry, L.L. (1994)."Reassessment of Expectations as a Comparison Standard in Measuring Service Quality: Implications for Further Research.” Journal of Marketing 58(1), 111-124.

[13] Ariely, D. (2000). Controlling the information flow: Effects on consumers' decision making and preferences. Journal of Consumer Research, 27(2), 233-248.

[14] Hoffman, D. L., \& Novak, T. P. (1996). Marketing in hypermedia computer-mediated environments: Conceptual foundations. Journal of marketing, 60(3), 131-145.

[15] Hoque, A. Y., \& Lohse, G. L. (1999). An Information Search Cost Perspective for Designing Interfaces for Electronic Commerce. Journal of Marketing Research (JMR), 36(3), 231-256.

[16] Schlosser, A. E., Shavitt, S., \& Kanfer, A. (1999). Survey of Internet users' attitudes toward Internet advertising. Journal of Interactive Marketing, 13(3), 34-54.

[17] Ranganathan, C., \& Ganapathy, S. (2002). Key dimensions of business-to-consumer web sites. Information \& Management, 39(6), 457-465.

[18] Bolton, L. E., \& Alba, J. W. (2006). Price fairness: Good and service differences and the role of vendor costs. Journal of Consumer Research, 33(2), 258-265. 
[19] Campbell, M. C. (2007). "Says who?!" How the source of price information and affect influence perceived price (un) fairness. Journal of Marketing Research, 44(2), 261-271.

[20] Daskalopoulou, I., \& Petrou, A. (2006). Consumers' expenditures and perceived price fairness. International Journal of Social Economics, 33(11), 766-780.

[21] Homburg, C., Hoyer, W. D., \& Koschate, N(2005). Customers’ reactions to price increases: do customer satisfaction and perceived motive fairness matter? Journal of the Academy of Marketing Science, 33(1), 36-49.

[22] Herrmann, A., Xia, L., Monroe, K. B., \& Huber, F. (2007). The influence of price fairness on customer satisfaction: an empirical test in the context of automobile purchases. Journal of Product \& Brand Management, 16(1), 49-58

[23] Crosby, L.A., Evans, K.R., \& Cowles, D. (1990).Relationship quality in services selling: an interpersonal influence perspective. Journal of Marketing, 54(3), 68-81..

[24]Dwyer, F. R., Paul H., \& Sejo, Oh. (1987). Developing buyer seller relations. Journal of Marketing, 51 (2), 11-28.

[25]Leuthesser L. (1997). Supplier relational behavior: an empirical assessment. Industrial marketing management, 26(3), 245-254.

[26]De Wulf, K., \& Steenhaut, S. (2003).The relationship between consumers unethical behavior and customer loyalty in a retail environment, Vlerick Leuven Gent Management School Working Paper Series , 17(8), 237-259.

[27]Ullman, J. B. (2001). Structural Equation Modeling. In B. G. Tabachnik, \& L. S. Fidell (Eds.), Using Multivariate Statistics (4th ed.): Allyn and Bacon. 